\begin{abstract}
Iranica
Abstracta Iranica Revue bibliographique pour le domaine irano-aryen

Volume 40-41 | 2019

Comptes rendus des publications de 2017-2018
\end{abstract}

\title{
Eran Almagor. Plutarch and the Persica
}

\section{Reinhard Pirngruber}

\section{(2) OpenEdition}

\section{Journals}

Electronic version

URL: http://journals.openedition.org/abstractairanica/50056

DOI: 10.4000/abstractairanica.50056

ISBN: 1961-960X

ISSN: 1961-960X

Publisher:

CNRS (UMR 7528 Mondes iraniens et indiens), Éditions de l'IFRI

Electronic reference

Reinhard Pirngruber, "Eran Almagor. Plutarch and the Persica", Abstracta Iranica [Online], Volume 40-41 ।

2019, document 83, Online since 30 December 2019, connection on 21 April 2021. URL: http://

journals.openedition.org/abstractairanica/50056 ; DOI: https://doi.org/10.4000/abstractairanica. 50056

This text was automatically generated on 21 April 2021.

Tous droits réservés 


\title{
Eran Almagor. Plutarch and the Persica
}

\author{
Reinhard Pirngruber
}

\section{REFERENCES}

Eran Almagor. Plutarch and the Persica. Edinburgh: Edinburgh University Press, 2018, 352 p., 1 map

1 This book provides an investigation of Plutarch's use of earlier Persica in his biography of Artaxerxes II, with pride of place dedicated to his adaptions of passages culled from the works of Ctesias and Deinon. Throughout the volume, the A. stresses the fact that Plutarch often significantly re-elaborated his source texts, rather than simply stringing together loosely related passages. Plutarch's work method is one of the core questions of this monograph; conversely, the A. is also interested in what his oeuvre can tell us about the sources he used.

2 In the introduction, the A. sketches his research questions and his methodology. He offers relevant background information to both Plutarch as a writer, his biographies and the Life of Artaxerxes, as well as to the genre of the Persica on which Plutarch drew for the latter work. Plutarch's interest in moral philosophy and the impact of Platonic ideas on Plutarch are repeatedly emphasized.

In the book's central part, Ctesias and Deinon are treated in two chapters each, while one is dedicated to Heracleides. For all authors, meticulous analyses are provided of which sections were incorporated by Plutarch into his Life of Artaxerxes and by what means, often to insightful results. The A. claims e.g., that Plutarch was acquainted with the works of Deinon only indirectly, and is able to demonstrate significant alterations to Ctesias' text by Plutarch aimed at underscoring the unreliability of the Cnidian. 


\section{AUTHORS}

\section{REINHARD PIRNGRUBER}

Institut für Orientalistik, Wien 